\title{
Effects of Ranibizumab and Aflibercept on Human Müller Cells and Photoreceptors under Stress Conditions
}

\author{
Weiyong Shen *, Belinda Yau, So-Ra Lee, Ling Zhu, Michelle Yam and Mark C. Gillies \\ Macula Research Group, Clinical Ophthalmology and Eye Health, Save Sight Institute, \\ The University of Sydney, Sydney, NSW 2000, Australia; belinda.yau@sydney.edu.au (B.Y.); \\ sora.lee@sydney.edu.au (S.-R.L.); ling.zhu@sydney.edu.au (L.Z.); michelle.yam@sydney.edu.au (M.Y.); \\ mark.gillies@sydney.edu.au (M.C.G.) \\ * Correspondence: weiyong.shen@sydney.edu.au; Tel.: +61-2-9382-7270; Fax: +61-2-9382-7138
}

Academic Editors: Claudio Bucolo and Chiara Maria Eandi

Received: 3 January 2017; Accepted: 24 February 2017; Published: 1 March 2017

\begin{abstract}
Anti-vascular endothelial growth factor (VEGF) therapy has revolutionized the treatment of retinal vascular diseases. However, constitutive VEGF also acts as a trophic factor on retinal non-vascular cells. We have studied the effects of aflibercept and ranibizumab on human Müller cells and photoreceptors exposed to starvation media containing various concentrations of glucose, with or without $\mathrm{CoCl}_{2}$-induced hypoxia. Cell survival was assessed by calcein-AM cell viability assays. Expression of heat shock proteins (Hsp) and redox proteins thioredoxin 1 and 2 (TRX1, TRX2) was studied by Western blots. The production of neurotrophic factors in Müller cells and interphotoreceptor retinoid-binding protein (IRBP) in photoreceptors was measured by enzyme-linked immunosorbent assays. Aflibercept and ranibizumab did not affect the viability of both types of cells. Neither aflibercept nor ranibizumab affected the production of neurotrophic factors or expression of Hsp60 and Hsp90 in Müller cells. However, aflibercept but not ranibizumab affected the expression of Hsp60, Hsp9, TRX1 and TRX2 in photoreceptors. Aflibercept and ranibizumab both inhibited the production of IRBP in photoreceptors, aflibercept more so than ranibizumab. Our data indicates that the potential influence of aflibercept and ranibizumab on photoreceptors should be specifically monitored in clinical studies.
\end{abstract}

Keywords: vascular endothelial growth factor; aflibercept; ranibizumab; Müller cells; photoreceptors; neurotrophic factors; heat shock proteins; redox proteins; interphotoreceptor retinoid-binding protein

\section{Introduction}

The functional integrity of the retinal vasculature is important for eye health. Neovascular age-related macular degeneration (AMD) and diabetic retinopathy are characterized by vascular leak and growth of abnormal blood vessels [1,2]. Disruption of the balance between angiogenic stimulators and inhibitors in pathological conditions can lead to vascular leak and growth of new blood vessels [1].

AMD is the leading cause of irreversible blindness among people aged $\geq 65$ years in the developed world. Neovascular AMD comprises only $10 \%-15 \%$ of all AMD cases but it accounts for $>80 \%$ of severe vision loss or legal blindness resulting from the disease [3]. Diabetic retinopathy is widely considered to be a neurovascular disease. Diabetic macular edema occurs when the blood retinal barrier is disrupted, causing vascular leak and accumulation of extracellular fluid and protein deposits [4]. Despite their different etiologies, vision loss in AMD and diabetic retinopathy is ultimately caused by neuronal degeneration. Vascular leak and neovascularization may exacerbate the underlying neuronal damage, thus contributing to vision loss. 
Vascular endothelial growth factor (VEGF) is a trophic endothelial growth factor that promotes endothelial migration, proliferation, survival and differentiation [1]. Overexpression of VEGF promotes vascular leak and ocular neovascularization. The advent of anti-VEGF agents such as ranibizumab (Lucentis) and aflibercept (Eylea) has revolutionized the treatment of retinal vascular diseases. Ranibizumab is a fully humanized small chain fragment that binds with high affinity to human VEGF-A, thereby preventing binding of VEGF-A to its receptors VEGFR-1 and VEGFR-2. Intravitreal injections of ranibizumab effectively reduce vascular leak and inhibit ocular neovascularization in clinical studies [1]. Aflibercept is a soluble VEGF decoy receptor that specifically recognizes and binds to VEGF-A, -B and placental growth factor (PLGF) [1,5]. Aflibercept is the newest anti-VEGF agent to be approved for treatment of neovascular AMD $[1,5]$.

A growing body of evidence indicates that constitutive VEGF also acts as a trophic factor on non-vascular cells and plays an important role in the maintenance and function of retinal ganglion cells, Müller cells, photoreceptors, the retinal pigment epithelium (RPE) and choriocapillaries [6-14]. Therefore, chronic inhibition of VEGF may cause unwanted adverse effects on these retinal and choroidal cells.

Müller cells are the major type of glial cells in the retina. Ensheathing all retinal neurons including photoreceptor cells, Müller cells protect retinal neurons via release of neurotrophins and the antioxidant glutathione [15]. Müller cells have been reported to release neurotrophic factors such as neurotropins, including brain-derived neurotrophic factor (BDNF), neurotrophins 3 and 4 (NT3 and NT4) and pigment epithelium derived factor (PEDF), contributing to the health of photoreceptors and other neurons in the retina [16-19].

A number of studies have recently tested the safety profiles of ranibizumab [20-23] and aflibercept [20,23] using human RPE cells [20-23], rat ganglion cell-like/neuronal progenitor cells [23] and mouse $661 \mathrm{w}$ photoreceptor cells [23]. However, currently there is little information on the effects of anti-VEGF therapy on human Müller cells and photoreceptors in vitro. In this study, we assessed the effects of clinical doses of ranibizumab and aflibercept on cell survival and differential expression of cell stress markers by human MIO-M1 Müller cells and Y79 photoreceptors under various stressed conditions. The effects of aflibercept and ranibizumab on the production of neurotrophic factors in Müller cells and interphotoreceptor retinoid-binding protein (IRBP) in photoreceptors were also evaluated.

\section{Results}

\subsection{Effects of Hyperglycemia and Hypoxia on the Survival of Müller Cells and Photoreceptors}

We compared Müller cells exposed to various stressed conditions with those cultured in medium containing $10 \%$ fetal calf serum (FCS) + low glucose (LG, $5 \mathrm{mM}$ ). We found that stress conditions consisting of $10 \% \mathrm{FCS}+\mathrm{LG}+\mathrm{CoCl}_{2}, 1 \% \mathrm{FCS}+\mathrm{LG}$ and $10 \% \mathrm{FCS}+$ high glucose $(\mathrm{HG}, 25 \mathrm{mM})$ did not significantly affect the viability of Müller cells (Figure 1A). However, the combination of 1\% FCS starvation with $\mathrm{CoCl}_{2}$-induced hypoxia or $\mathrm{HG}$ significantly reduced the Müller cell viability (Figure $1 \mathrm{~A}$ ). In Y79 photoreceptors, significant reduction of cell viability was observed when photoreceptors were incubated under stressed conditions including $10 \% \mathrm{FCS}+\mathrm{CoCl}_{2}, 1 \% \mathrm{FCS}$ starvation alone or $1 \% \mathrm{FCS}$ starvation $+\mathrm{CoCl}_{2}$, regardless of the concentration of glucose (Figure 1B). High glucose (25 mM, HG) also significantly reduced the viability of Y79 cells compared with cells incubated in RPMI medium containing 10\% FCS and $11 \mathrm{mM}$ glucose (LG) (Figure 1B). 

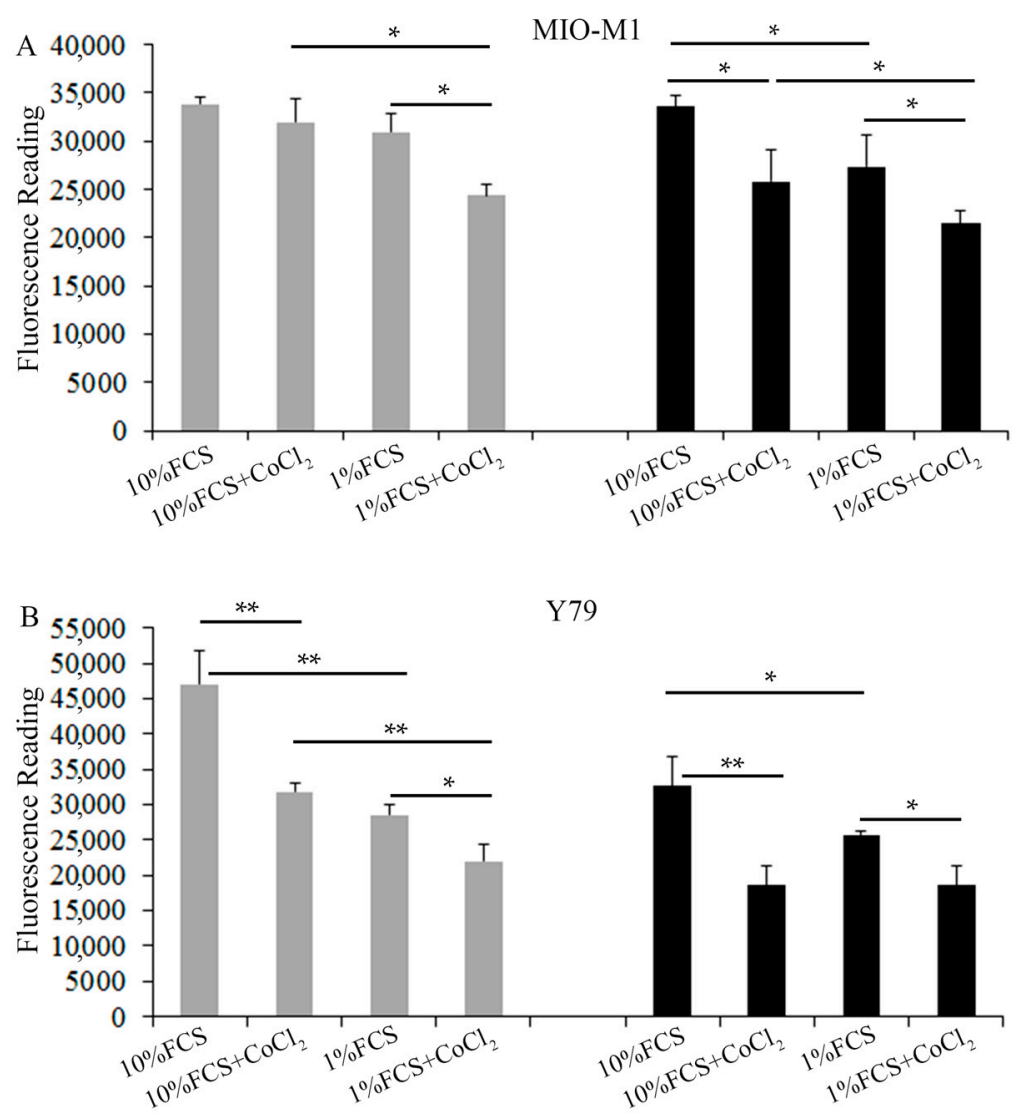

Figure 1. Effects of serum starvation, high glucose and hypoxia on cell survival of Müller cells and photoreceptors. Cell survival was measured by calcein-AM cell viability assays $24 \mathrm{~h}$ after incubating cells in test media. (A) Müller cell viability assays. Grey bars: $5 \mathrm{mM}$ glucose. Black bars: $25 \mathrm{mM}$ glucose. ${ }^{*} p<0.05, n=6$ /group; (B) Y79 cell viability assays. Grey bars: $11 \mathrm{mM}$ glucose. Black bars: 25 mM glucose. ${ }^{*} p<0.05$ and ${ }^{* *} p<0.01$ respectively, $n=6 /$ group. FCS, fetal calf serum.

2.2. Effects of Cell Stress on Vascular Endothelial Growth Factor (VEGF)-A Production and Hypoxia-Inducible Factor $1 \alpha$ (HIF1 $\alpha)$ Expression in Müller Cells and Photoreceptors

In order to study the effects of stress on VEGF production by Müller cells and photoreceptors, we collected conditioned media for VEGF ELISA $24 \mathrm{~h}$ after culturing both types of cells in starvation media containing $1 \%$ FCS and various concentrations of glucose with and without $\mathrm{CoCl}_{2}$-induced hypoxia (Figure 2A). As expected, $\mathrm{CoCl}_{2}$-induced hypoxia significantly increased VEGF production in Müller cells and photoreceptors compared with the corresponding groups without hypoxia (Figure 2A). However, HG appeared to have little effect on the production of VEGF in both types of cells when compared with the corresponding groups cultured in media containing low glucose (Figure 2A).

As HIF1 $\alpha$ regulates VEGF expression, we next performed Western blots to study changes in HIF1 $\alpha$ expression in Müller cells and Y79 photoreceptors after exposure to starvation media containing $1 \%$ FCS and various concentrations of glucose, with and without $\mathrm{CoCl}_{2}$-induced hypoxia (Figure $2 \mathrm{~B}$ ). Consistent with the results of VEGF production, $\mathrm{CoCl}_{2}$-induced hypoxia significantly increased $\mathrm{HIF} 1 \alpha$ expression in both types of retinal cells compared with the corresponding groups without hypoxia, while HG had little effect on HIF1 $\alpha$ expression when compared with the corresponding groups cultured in LG media (Figure 2B). 


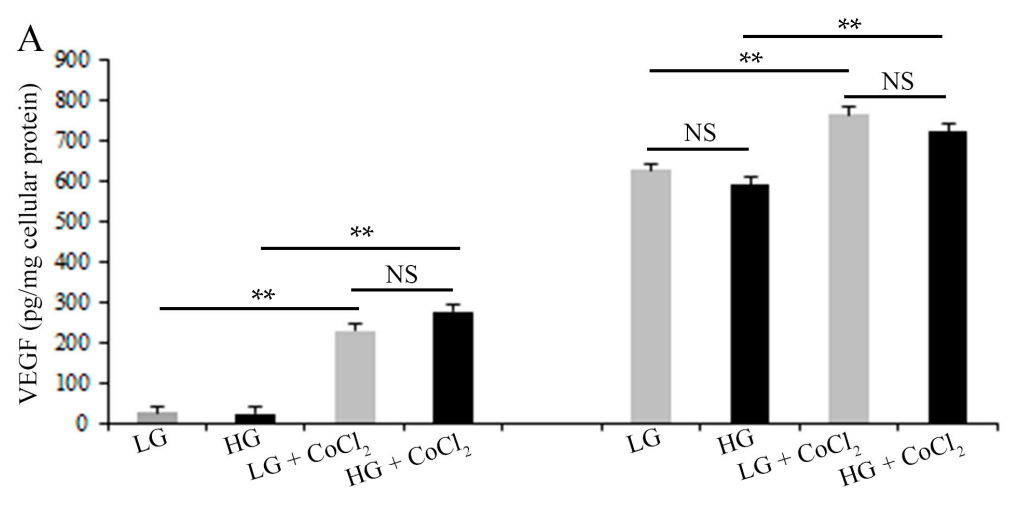

MIO-M1

Y79

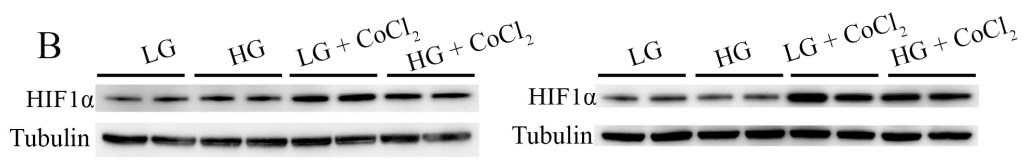

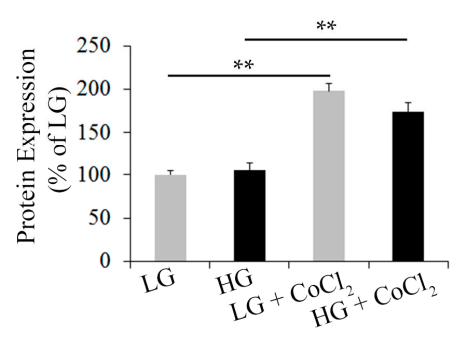

MOI-M1

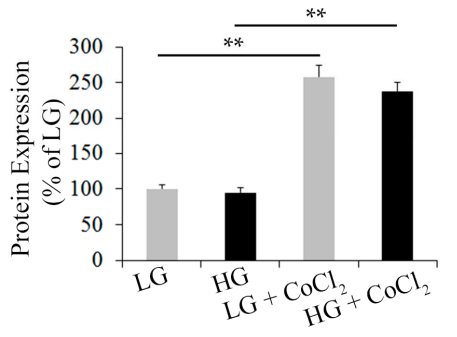

Y79

Figure 2. Effects of cell stress on VEGF-A and HIF1 $\alpha$ expression in Müller cells and Y79 photoreceptors. (A) VEGF-A was measured by ELISA using conditioned media collected from MIO-M1 and Y79 cells, $n=4-5$ /group in Müller cells and $n=8$ /group in Y79 photoreceptors, ${ }^{* *} p<0.01$; (B) Western blots for HIF1 $\alpha$ using cellular proteins, $n=4$ /group, ${ }^{* *} p<0.01$. For MIO-M1 Müller cells: Grey bars: $5 \mathrm{mM}$ glucose. Black bars: $25 \mathrm{mM}$ glucose. For Y79 photoreceptors: Grey bars: $11 \mathrm{mM}$ glucose. Black bars: $25 \mathrm{mM}$ glucose. NS, not significant; LG, low glucose; HG, high glucose.

\subsection{Effects of Aflibercept and Ranibizumab on Müller Cell Survival}

After establishing the in vitro cell stress model in MIO-M1 Müller cells, we next tested the effects of anti-VEGF therapy on cell viability $24 \mathrm{~h}$ after incubating Müller cells in various stress media containing clinical doses of aflibercept (Eylea, $0.5 \mathrm{mg} / \mathrm{mL}$ ) and ranibizumab (Lucentis, $0.125 \mathrm{mg} / \mathrm{mL}$ ). Fluorescence microscopy of Müller cells stained with calcein-AM did not reveal changes in Müller cell morphology under the tested stress conditions (Figure 3A-L). Measurements of fluorescence intensity after calcein-AM staining indicated that $\mathrm{CoCl}_{2}$-induced hypoxia significantly reduced the Müller cell viability (Figure 3M). However, treatment with ranibizumab and aflibercept did not affect Müller cell survival when compared with each corresponding group cultured in starvation media containing various concentrations of glucose, with or without $\mathrm{CoCl}_{2}$-induced hypoxia (Figure $3 \mathrm{M}$ ). 

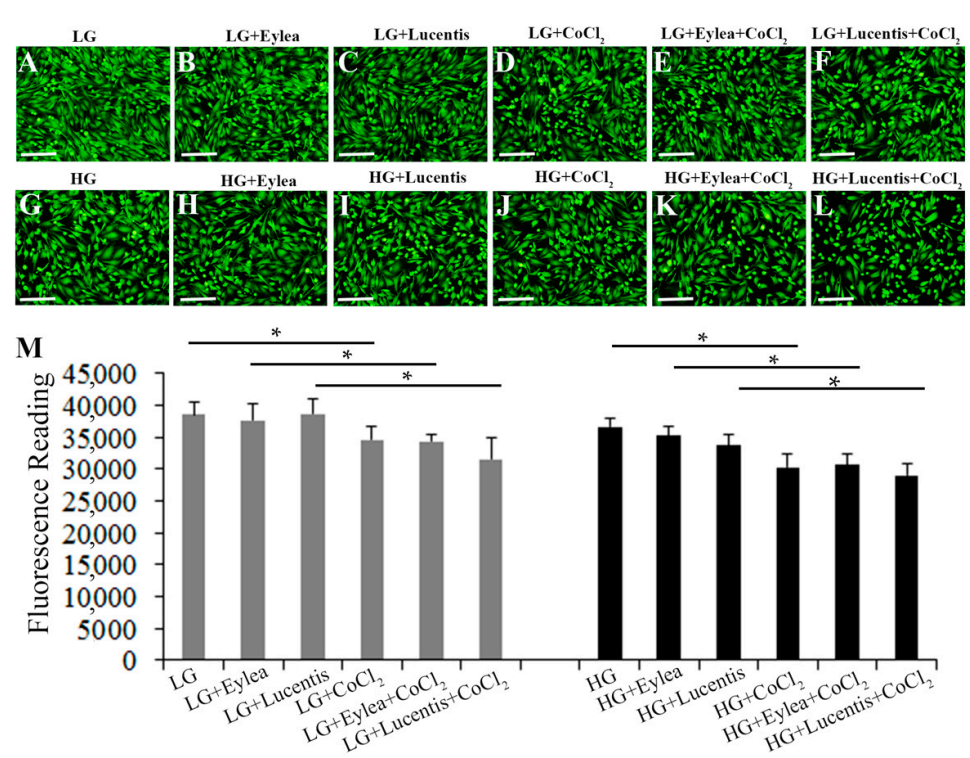

Figure 3. Aflibercept (Eylea, $0.5 \mathrm{mg} / \mathrm{mL}$ ) and ranibizumab (Lucentis, $0.125 \mathrm{mg} / \mathrm{mL}$ ) did not affect Müller cell survival under stress conditions. (A-L) Fluorescence images of calcein-AM-stained Müller cells exposed to stress media for $24 \mathrm{~h}$. Scale bars: $50 \mu \mathrm{m}$; (M) Quantitative analysis of Müller cell viability by measuring fluorescence intensity after staining Müller cells with calcein-AM. ${ }^{*} p<0.05$, $n=6 /$ group.

\subsection{Effects of Aflibercept and Ranibizumab on Photoreceptor Cell Viability}

Fluorescence microscopy of Y79 photoreceptors stained with calcein-AM indicated that addition of aflibercept and ranibizumab into starvation media containing LG or HG did not affect Y79 cell survival but $\mathrm{CoCl}_{2}$-induced hypoxia reduced the cell viability (Figure $4 \mathrm{~A}-\mathrm{L}$ ). This observation was further confirmed by quantitative measurement of fluorescence intensity after staining Y79 photoreceptors with calcein-AM (Figure 4M).

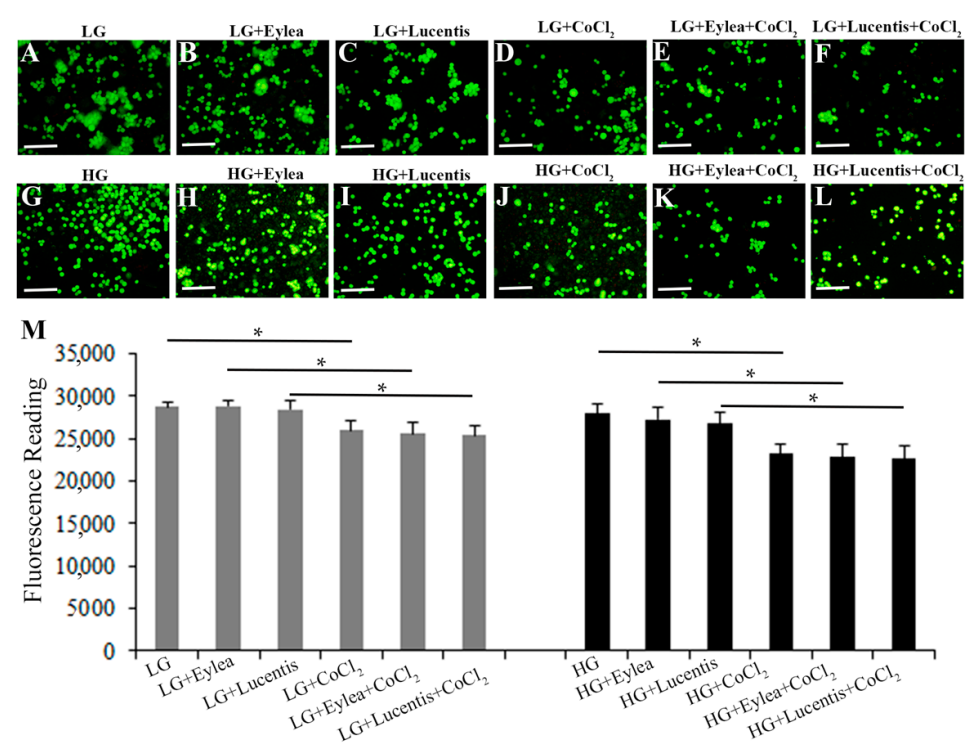

Figure 4. Aflibercept and ranibizumab did not affect $Y 79$ photoreceptor cell survival under stress conditions. (A-L) Fluorescence images of calcein-AM-stained Y79 cells exposed to stress media containing LG (11 mM) or HG (25 mM) for $24 \mathrm{~h}$. Scale bars: $50 \mu \mathrm{m}$; (M) Quantitative analysis of Y79 cell viability by measuring the fluorescence intensity after staining Y79 cells with calcein-AM. * $p<0.05, n=6 /$ group. 


\subsection{Effects of Aflibercept and Ranibizumab on Hsp60 and Hsp90 Expression in Müller Cells}

In order to study the effects of anti-VEGF therapy on mitochondrial and cytoplasmic stress in Müller cells, we assessed whether ranibizumab and aflibercept affected the expression of Hsp60 and Hsp90 under stress (Figure 5). Hsp70 and Hsp90 are molecular chaperones that are expressed constitutively under normal conditions to maintain protein homeostasis and both are upregulated by environmental stress [24,25]. Hsp60 has primarily been known as a mitochondrial protein that is important for folding key proteins in the mitochondria [25]. Hsp90 interacts with unfolded proteins to prevent irreversible protein aggregation and assists refolding, intracellular transport, maintenance and degradation of proteins in the cytoplasm [24]. We found that hypoxia and HG, either alone or in combination, tended to increase the expression of Hsp60 and Hsp90 when compared with the groups cultured in starvation media containing LG (Figure 5A,B). However, ranibizumab and aflibercept did not have a significant impact on the expression of Hsp60 and Hsp90 in Müller cells under the stress conditions we tested (Figure 5A,B).
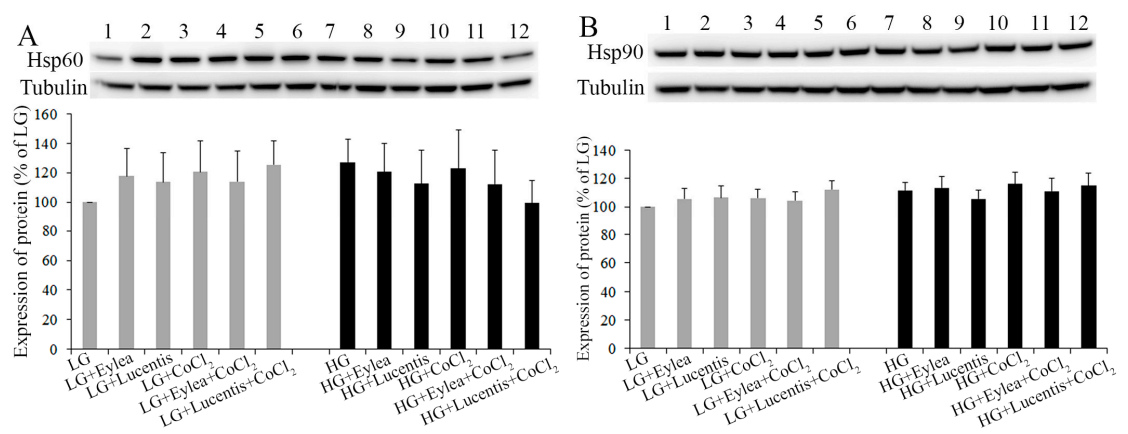

Figure 5. Effects of aflibercept and ranibizumab on Hsp60 and Hsp90 expression in Müller cells under stress conditions. Müller cells were incubated in stress media for $24 \mathrm{~h}$. The effects of aflibercept and ranibizumab on Hsp60 (A); and Hsp90 (B) expression were studied by Western blots, $n=4$ /group.

\subsection{Effects of Aflibercept and Ranibizumab on Hsp60 and Hsp90 Expression in Photoreceptors}

We also conducted Western blots to study the effects of aflibercept and ranibizumab on expression of Hsp60, Hsp90 in Y79 cells exposed to stress conditions. We found that the addition of aflibercept into culture media significantly inhibited the expression of Hsp60 compared with cells cultured in starvation media containing LG, LG $+\mathrm{CoCl}_{2}$ or HG $(p<0.05$, Figure $6 \mathrm{~A})$, and tended to decrease Hsp60 expression in cells cultured in $\mathrm{HG}+\mathrm{CoCl}_{2}$ (Figure 6A). Aflibercept significantly increased the expression of $\mathrm{Hsp} 90$ in cells cultured in $\mathrm{LG}+\mathrm{CoCl}_{2}$ (Figure 6B). However, ranibizumab did not have a significant effect on the expression of Hsp60 and Hsp90 in Y79 cells under the stress conditions we tested (Figure 6A,B).
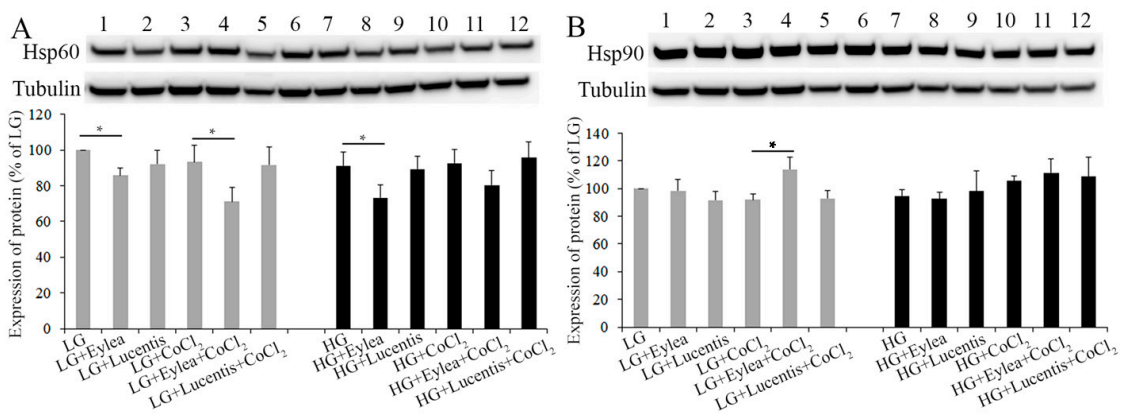

Figure 6. Effects of aflibercept and ranibizumab on Hsp60 and Hsp90 expression in Y79 photoreceptors. Y79 cells were incubated in stress media for $24 \mathrm{~h}$. The effects of aflibercept and ranibizumab on Hsp60 (A); and Hsp90 (B) were studied by Western blots. * $p<0.05, n=6$ /group. 


\subsection{Effects of Aflibercept and Ranibizumab on Thioredoxin 1 and 2 (TRX1, TRX2) Expression in} Photoreceptors

As our data from Western blots indicated that aflibercept affected the expression of Hsp60 and Hsp90 in Y79 photoreceptors, we next studied the effects of aflibercept and ranibizumab on expression of redox proteins including thioredoxin 1 and 2 (TRX1, TRX2) in Y79 cells. TRX1 is present in the cytosol, while TRX2 is localized to mitochondria [26]. We found that addition of aflibercept into starvation media containing $\mathrm{LG}+\mathrm{CoCl}_{2}$ or $\mathrm{HG}+\mathrm{CoCl}_{2}$ significantly increased the expression of TRX1 and TRX2, while ranibizumab did not affect TRX1 and TRX2 expression in Y79 photoreceptors cultured in LG or $\mathrm{HG}$, either with or without $\mathrm{CoCl}_{2}$-induced hypoxia (Figure 7).
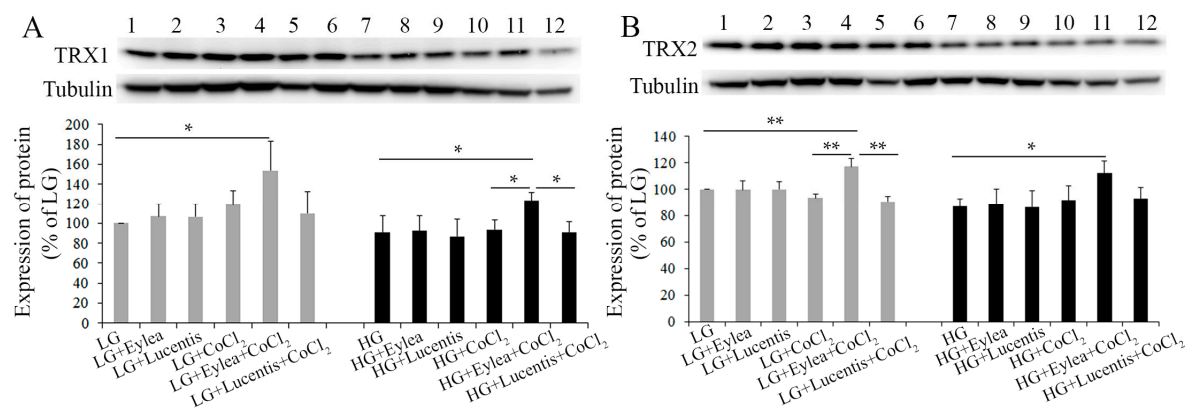

Figure 7. Effects of aflibercept and ranibizumab on expression of TRX1 (A) and TRX2 (B) in photoreceptor cells. Aflibercept significantly increased the expression of TRX1 and TRX2 under stress conditions caused by $\mathrm{CoCl}_{2}$-induced hypoxia. However, ranibizumab had little effects on the expression of TRX1 and TRX2 under the conditions tested. ${ }^{*} p<0.05$ and ${ }^{* *} p<0.01, n=4$ /group. TRX, thioredoxin.

\subsection{Effects of Aflibercept and Ranibizumab on Neurotrophic Factors in Müller Cells}

As Müller cells play an important role in the maintenance of photoreceptor health through production of neurotrophic factors, we next studied the effects of aflibercept and ranibizumab on the production of NT3, BDGF and PEDF under stress conditions. Compared with cells cultured in the starvation medium containing LG, HG had little effect on NT3 production but $\mathrm{CoCl}_{2}$-induced hypoxia significantly increased NT3 production regardless of the concentrations of glucose (Figure 8A). Addition of clinical doses of aflibercept and ranibizumab into the culture media did not have a significant impact on NT3 production in Müller cells cultured in the stress conditions we tested (Figure 8A).

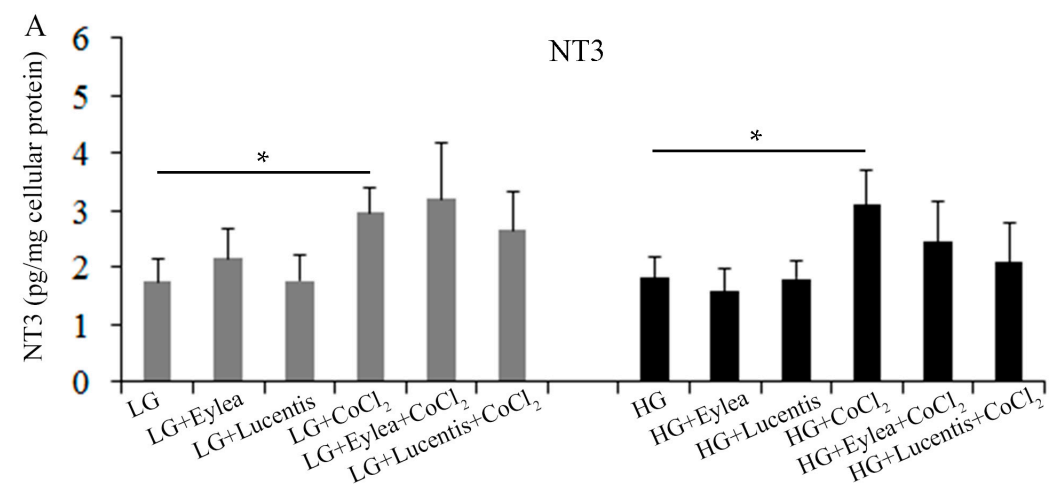

Figure 8. Cont. 

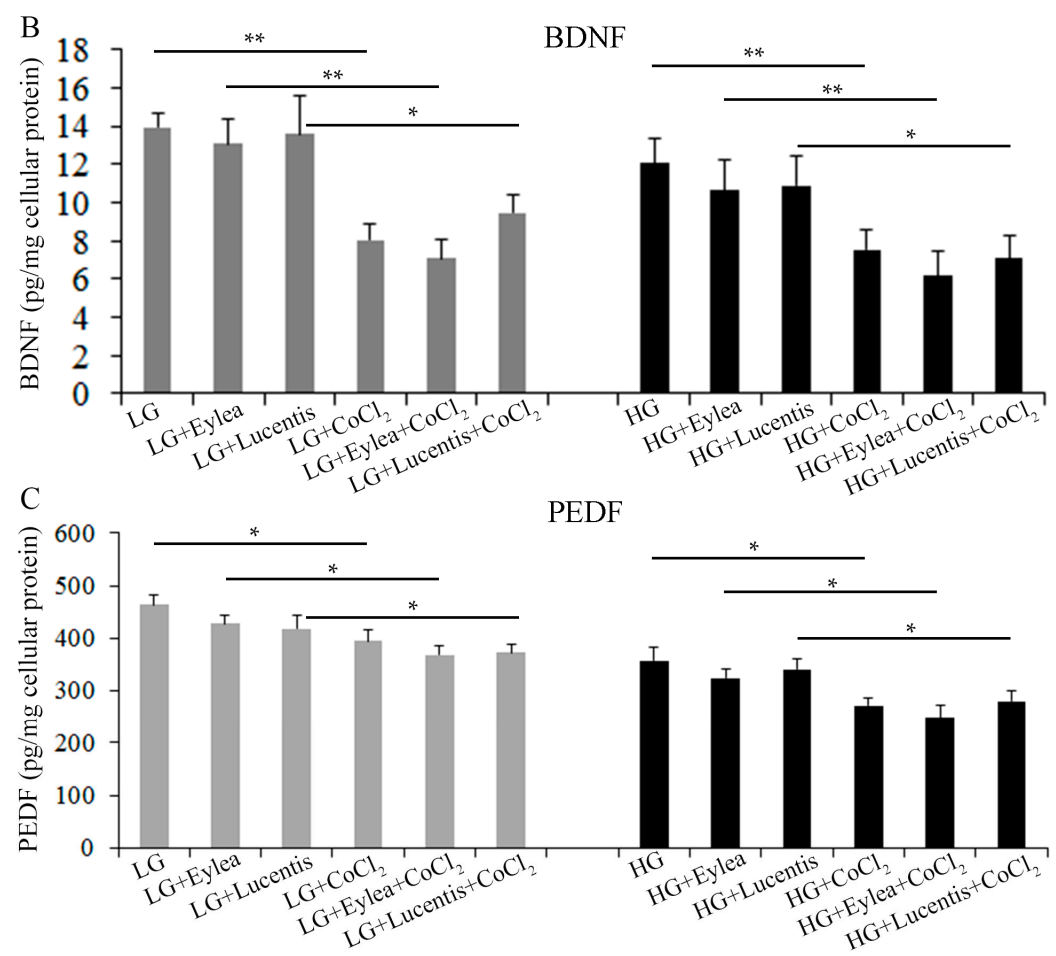

Figure 8. Aflibercept and ranibizumab did not affect the production of NT3, BDNF and PEDF in Müller cells. (A) Hypoxia significantly increased NT3 production compared with cells incubated in the medium containing LG or HG; $(\mathbf{B}, \mathbf{C})$ Hypoxia significantly reduced BDNF and PEDF and HG also significantly reduced PEDF production in (C). However, the addition of aflibercept and ranibizumab into media did not significantly affect the production of NT3, BDNF and PEDF in (A-C). ${ }^{*} p<0.05$ and ** $p<0.01, n=9$ /group in (A) and $n=6$ /group in (B,C). NT3, neurotrophin 3; BDNF, brain-derived neurotrophic factor; PEDF, pigment epithelium derived factor.

2.9. Effects of Aflibercept and Ranibizumab on Interphotoreceptor Retinoid-Binding Protein (IRBP) Production in Y79 Photoreceptors

Measurements of BDNF and PEDF production indicated that hypoxia significantly inhibited the production of BDNF and PEDF in Müller cells cultured in starvation media containing LG or HG (Figure 8B,C). However, neither aflibercept nor ranibizumab affected the levels of BDNF and PEDF production under stress conditions (Figure 8B,C).

As IRBP is expressed by Y79 photoreceptor cells and plays an important role in the visual cycle through transport of 11-cis retinal and all-trans retinol between the photoreceptors and RPE cells [27-31], we next determined the effects of aflibercept and ranibizumab on the production of IRBP in Y79 photoreceptors (Figure 9). Compared with cells cultured in the starvation medium containing LG, HG slightly reduced the production of IRBP but the differences were not statistically significant ( $p>0.05$, Figure 9). Hypoxia significantly reduced the production of IRBP regardless the concentrations of glucose ( $p<0.05$, LG vs. $\mathrm{LG}+\mathrm{CoCl}_{2}$ and $\mathrm{HG}$ vs. $\mathrm{HG}+\mathrm{CoCl}_{2}$; Figure 9). Addition of clinical doses of aflibercept and ranibizumab into culture media significantly inhibited the production of IRBP and this inhibitory effect was more profound in cells treated with aflibercept than in those treated with ranibizumab under each stress condition (Figure 9). Interestingly, aflibercept but not ranibizumab, appeared to have less effect on inhibiting IRBP in cells exposed to hypoxia regardless of the concentrations of glucose (Figure 9). 


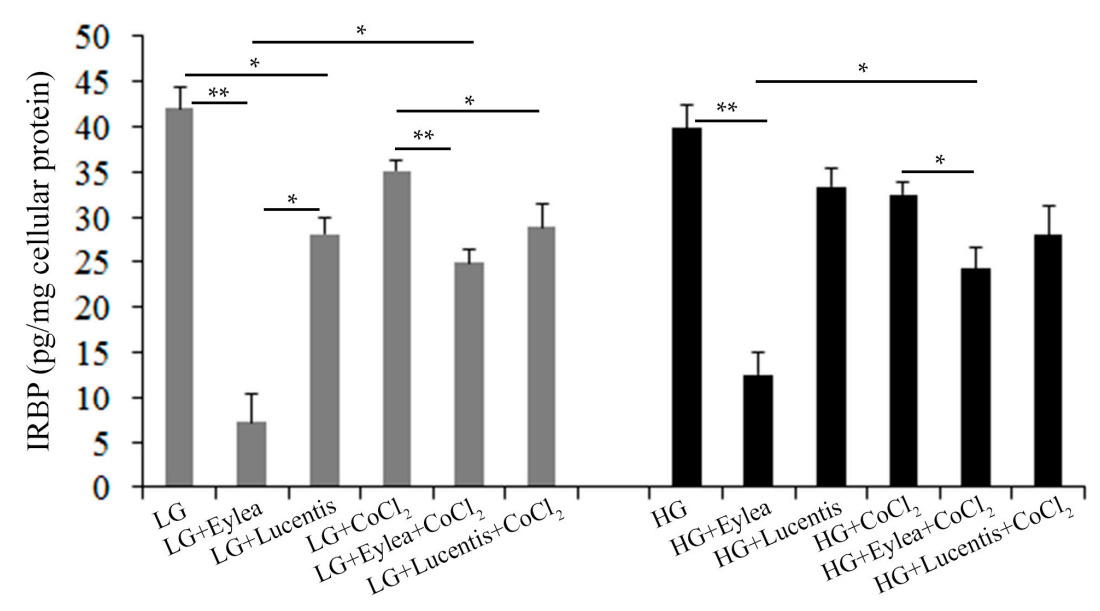

Figure 9. Aflibercept and ranibizumab inhibited IRBP production in Y79 photoreceptor cells. IRBP was measured by ELISA using conditioned media collected from $Y 79$ cells $24 \mathrm{~h}$ after incubation in stress media containing $1 \%$ FCS. ${ }^{*} p<0.05$ and ${ }^{* *} p<0.01, n=5$ /group.

\section{Discussion}

We have studied the potential adverse effects of aflibercept and ranibizumab on human MIO-M1 Müller cells and Y79 photoreceptors under various conditions of stress in vitro. We did not find direct evidence that aflibercept and ranibizumab affected the viability of either type of cells. Neither aflibercept nor ranibizumab affected the production of neurotrophic factors, including NT3, BDNF and PEDF, by Müller cells, nor did they affect the expression of cell stress markers, including Hsp60 and Hsp90. In photoreceptors, however, aflibercept but not ranibizumab, affected the expression of heat shock proteins including Hsp60 and Hsp90 and redox proteins including TRX1 and TRX2. Our most interesting finding was that both aflibercept and ranibizumab inhibited the production of IRBP in Y79 photoreceptors, with the most profound effect observed with aflibercept treatment. Collectively, we found that aflibercept and ranibizumab did not have adverse effects on human Müller cells but their potential influence on photoreceptors should be specifically monitored in clinical research.

Of the various forms of stress we induced, we found that hypoxia was the main factor that drove cell injury and overexpression of VEGF and HIF1 $\alpha$ in Müller cells. This observation is consistent with the well-established role of VEGF and HIF1 $\alpha$ in mediating neovascularization in ischemic retinal diseases [1,2,32]. VEGF is produced by several types of retinal cells, including Müller cells and RPE cells. Under pathological conditions, exogenous stress leads to morphological, biochemical and physiological changes in Müller cells, including uncontrolled production of VEGF, thus contributing to breakdown of the blood retinal barrier and the development of retinal neovascularization. Müller cells are a major contributor to retinal vascular leakage and pre-retinal and intra-retinal neovascularization in diabetic retinopathy [33].

Y79 photoreceptors have been reported to overexpress VEGF under hypoxic conditions [34]. We confirmed that hypoxia was the main factor that drove cell injury and overexpression of VEGF and HIF1 $\alpha$ in Y79 photoreceptors. Photoreceptor cells are the most prevalent cells in the retina. They have a very high metabolic rate and consume more oxygen than other cells throughout the body. There is increasing evidence that photoreceptor cells play a previously unappreciated role in retinal diseases. It has been reported that stressed photoreceptors likely contribute to retinal hypoxia and subsequent retinal abnormalities in early and advanced stages of diabetic retinopathy [35-37]. Du et al. [38] reported that photoreceptors were the major source of reactive oxygen species in the retina. Genetic and chemical depletion of photoreceptors inhibited increase in superoxide and inflammatory proteins in diabetic mice [38]. A recent study by Joyal et al. demonstrated that stressed photoreceptors secreted VEGF through stabilizing HIF1 $\alpha$ and contributed to deep retinal neovascularization in VLDLR mutant mice [39]. Collectively, these observations indicate that the high energy demand 
by photoreceptors makes them vulnerable to cell injury under stress conditions such as hypoxia, hyperglycemia and energy starvation, thus acting as both a victim and a contributor to vascular abnormalities in diseased conditions.

We did not find direct evidence that the clinical doses of aflibercept and ranibizumab affected the survival of human MIO-M1 Müller cells and Y79 photoreceptors. This result is consistent with findings reported by others that clinical doses of aflibercept, ranibizumab and bevacizumab did not affect the cell survival of human RPE, rat ganglion cells or mouse 661w photoreceptors [20-23,40], However, a recent study found that at $10 \times$ clinical doses, aflibercept, but not ranibizumab, significantly decreased the cell viability of human RPE [20]. Aflibercept at $2 \times$ and $10 \times$ clinical doses also caused damage to mitochondria in the RPE [20]. We have studied the effects of clinical doses of aflibercept and ranibizumab on the expression of mitochondrial stress marker Hsp60 and cytoplasmic stress marker Hsp90 along with redox proteins including TRX1 and TRX2 in Müller cells and Y79 photoreceptors. We found that aflibercept and ranibizumab had little direct effect on Müller cells. In photoreceptors, however, aflibercept, but not ranibizumab, caused differential expression of Hsp60, Hsp90; TRX1 and TRX2, indicating that photoreceptors may be more susceptible to aflibercept-induced cellular toxicity.

A number of recent studies have reported the adverse effects of anti-VEGF therapy in vitro and in vivo. Brar et al. reported that VEGF protected retinal ganglion cells against $\mathrm{H}_{2} \mathrm{O}_{2}$-mediated oxidative stress but this protective effect was eliminated by co-treatment with bevacizumab [10]. Pretreatment of the RPE with neutralizing antibodies against VEGF-A promoted $\mathrm{H}_{2} \mathrm{O}_{2}$-induced cell death [8]. In a rat model of ischemia-reperfusion injury, ischemic preconditioning increased the levels of VEGF-A expression and substantially decreased cell apoptosis in ganglion cells and the inner retinal neurons and the neuroprotective effect of ischemic preconditioning was reversed by VEGF-A inhibition [41]. Chronic inhibition of VEGF-A using soluble VEGF-R1 was reported to lead to loss of retinal ganglion cells in normal rats [41]. Klettner et al. reported that aflibercept but not ranibizumab was taken up and stored in the RPE, leading to reduced phagocytic ability and impaired wound healing capacity [42,43]. Considering that photoreceptors do not have the capacity of phagocytosis, the cellular mechanisms underlying aflibercept-induced stress in photoreceptors would be different from that observed in the RPE. Intravitreal injection of bevacizumab disrupted mitochondria in the photoreceptor inner segments and caused a significant increase in photoreceptor apoptosis [44,45]. Sustained neutralization of intraocular VEGF has been reported to induce retinal neurodegeneration in diabetic mice [11]. Januschowski et al. observed significant reduction in a-wave and b-wave amplitudes after short-term exposure of isolated bovine retinas to an oxygen-saturated nutrient solution containing aflibercept [46]. Genetic disruption of VEGF expression in the RPE led to choriocapillary atrophy, RPE and Bruch's membrane abnormalities, increased photoreceptor apoptosis and reduced cone photoreceptor function $[6,7,14]$. Collectively, these data suggest the potential adverse effects of anti-VEGF therapy should be carefully evaluated in all types of retinal cells.

One important function of Müller cells is to release neurotrophic factors such as NT3, BDNF and PEDF to maintain the health of photoreceptors and other neurons [18,47-50]. We next studied the effects of aflibercept and ranibizumab on the production of NT3, BDNF and PEDF in human Müller cells. We found that hypoxia increased NT3 and reduced the production of BDNF and PEDF. However, aflibercept and ranibizumab did not significantly affect the production of these neurotrophic factors by Müller cells under the stress conditions we tested. Since aflibercept and ranibizumab did not affect the cell viability and expression of Hsp60 and Hsp90 in Müller cells, we believe that clinical doses of aflibercept and ranibizumab are not toxic to Müller cells.

Perhaps our most interesting finding was that aflibercept and ranibizumab inhibited the production of IRBP in photoreceptors. IRBP is a major soluble glycoprotein secreted by photoreceptors [51]. It is distributed within the interphotoreceptor matrix (IPM) in a light-dependent manner and participates in the intimate interactions between the IPM and photoreceptors [52]. IRBP is important for the maintenance of the function of photoreceptors through transport of 11-cis retinal and all-trans retinol between the photoreceptors and RPE cells in the visual cycle, buffering excess 
vitamin A in the IPM and protecting retinoids from degradation [52]. IRBP deficiency has been linked to photoreceptor damage in a number of retinal diseases including inherited retinal diseases [53] and diabetic retinopathy [31]. We found that clinical doses of aflibercept and ranibizumab significantly inhibited the production of IRBP in Y79 photoreceptors, with the most profound effect observed with aflibercept treatment. Data from Western blots indicated that aflibercept, but not ranibizumab, affected the expression of mitochondrial markers Hsp60 and TRX2 as well as cytoplasmic marker Hsp90 and TRX1 in Y79 cells, suggesting that aflibercept may stress photoreceptors more than ranibizumab does.

Interestingly, we found that aflibercept, but not ranibizumab, had less effect on inhibiting IRBP in hypoxia when compared with cells treated with aflibercept in normoxia. One possible explanation for this observation could be that hypoxia induces overexpression of VEGF-B and PLGF [54] and both angiogenic factors may inhibit the production of IRBP. Given the facts that aflibercept inhibits VEGF-A, -B and PLGF while ranibizumab mainly acts on VEGF-A, aflibercept may partially reverse the inhibitory effects of hypoxia-induced overexpression of VEGF-B and PLGF on IRBP production. Future experiments are warranted to study the effects of different isoforms of VEGF family members on IRBP production in photoreceptors.

We acknowledge that there are limitations in extrapolating findings from in vitro studies to the clinic. Isolation and culture of photoreceptor cells from normal eyes has been a major challenge for retinal research. This is because that normal photoreceptor cells would not survive for very long once deprived of their normal extracellular matrix and cellular contacts with other retinal cells such as the RPE and Müller cells. Since Y79 photoreceptors were originally derived from a human retinoblastoma, they may not act as normal human photoreceptors in vitro in every respect although they express several markers of differentiated photoreceptors including opsin, arrestin, phosducin and IRBP [27-31]. Therefore, our results cannot be readily extrapolated to the clinical setting but may nevertheless be useful to generate hypotheses for testing in clinical trials.

\section{Materials and Methods}

\subsection{Culture of Human Müller Cells and Photoreceptors under Normal and Stressed Conditions}

Human MIO-M1 Müller cells were cultured in DMEM (GIBCO\#11885, Grand Island, NY, USA), and retinoblastoma Y79 photoreceptor cells (ATCC ${ }^{\circledR} \mathrm{HTB}^{\mathrm{TM}}$, Manassas, VA, USA) were cultured in RPMI1640 (Invitrogen\#11875, Sydney, Australia) media containing 10\% fetal calf serum (FCS), $1 \mathrm{mg} / \mathrm{mL}$ glutamine, $100 \mathrm{U} / \mathrm{mL}$ penicillin and $100 \mathrm{U} / \mathrm{mL}$ streptomycin. The media were supplemented with various concentrations of glucose to mimic physiologic and hyperglycemic conditions. In order to induce a hypoxic environment, cobalt chloride $\left(\mathrm{CoCl}_{2}, 200 \mu \mathrm{M}\right.$, Sigma, St. Louis, MO, USA) added to media to induce hypoxia-related cell stress [55]. $\mathrm{CoCl}_{2}$ establishes the cellular hypoxic response via stabilizing hypoxia-inducible factors through inhibition of the prolyl hydroxylase domain [56,57]. For experiments in which cells were exposed to hypoxic stress, cells were initially cultured in media containing 10\% FCS and $5 \mathrm{mM}$ glucose for MIO-M1 cells or $11 \mathrm{mM}$ glucose for Y79 cells and then stressed in "starvation" media containing $1 \%$ FCS, various concentrations of glucose, $1 \%$ insulin-transferrin-selenium-ethanolamine supplements (ITS-X, GIBCO\#51500056), $1 \mathrm{mg} / \mathrm{mL}$ glutamine, $100 \mathrm{U} / \mathrm{mL}$ penicillin and $100 \mathrm{U} / \mathrm{mL}$ streptomycin along with or without $\mathrm{CoCl}_{2}(200 \mu \mathrm{M})$. In order to study the effects of aflibercept (Eyelea) and ranibizumab (Lucentis) on Müller cells and photoreceptors, both types of retinal cells were treated with these two anti-VEGF agents for $24 \mathrm{~h}$ under hypoxic stress as described below.

\subsection{Anti-VEGF Treatments in Human Müller Cells and Photoreceptors}

Clinical doses of aflibercept $(0.5 \mathrm{mg} / \mathrm{mL})$ and ranibizumab $(0.125 \mathrm{mg} / \mathrm{mL})$ were dissolved in starvation media containing $1 \%$ FCS, various concentrations of glucose along with and without $\mathrm{CoCl}_{2}(200 \mu \mathrm{M})$ (Table 1). The clinical doses were calculated by assuming that the amount of each drug used clinically in intravitreal injections distributes equally throughout the $4 \mathrm{~mL}$ of human 
vitreous. Müller cells and Y79 photoreceptors were incubated in 12 starvation media containing 1\% FCS and other elements including: (1) low glucose (LG); (2) LG + aflibercep; (3) LG + ranibizumab; (4) $\mathrm{LG}+\mathrm{CoCl}_{2}\left(200 \mu \mathrm{M}\right.$; (5) $\mathrm{LG}+\mathrm{CoCl}_{2}+$ aflibercep; (6) $\mathrm{LG}+\mathrm{CoCl}_{2}+$ ranibizumab; (7) high glucose (HG), (8) HG + aflibercep; (9) HG + ranibizumab; (10) $\mathrm{HG}+\mathrm{CoCl}_{2}$; (11) $\mathrm{HG}+\mathrm{CoCl}_{2}+$ aflibercep; and (12) $\mathrm{HG}+\mathrm{CoCl}_{2}+$ ranibizumab (Table 1). The effects of aflibercept and ranibizumab on cell survival, differential expression of cell stress markers and the production of NT3, BDNF and PEDF as well as IRBP were assessed $24 \mathrm{~h}$ after incubation as described below.

Table 1. Stress conditions in which $1 \%$ FCS starvation media were used to test the effects of anti-VEGF therapy on MIO-M1 Müller cells and Y79 photoreceptors.

\begin{tabular}{ccccc}
\hline Group & Glucose (LG/HG) & $\mathrm{CoCl}_{\mathbf{2}}(\mathbf{2 0 0} \mu \mathrm{M})$ & Aflibercept $(0.5 \mathrm{mg} / \mathrm{mL})$ & Ranibizumab $(0.125 \mathrm{mg} / \mathrm{mL})$ \\
\hline 1 & LG & - & - & - \\
2 & LG & - & + & - \\
3 & LG & - & - & + \\
4 & LG & + & - & - \\
5 & LG & + & + & + \\
6 & LG & + & - & - \\
7 & HG & - & + & - \\
8 & HG & - & - & + \\
9 & HG & - & - & - \\
10 & HG & + & + & + \\
11 & HG & + & - & + \\
12 & HG & + & -
\end{tabular}

LG = low glucose, $5 \mathrm{mM}$ for MIO-M1 Müller cells and $11 \mathrm{mM}$ for Y79 photoreceptors respectively; HG = high glucose, $25 \mathrm{mM}$ for both types of retinal cells. All media were supplemented with $1 \%$ insulin-transferrin-selenium-ethanolamine supplements (ITS-X, GIOCO\#51500056).

\subsection{Calcein-AM Cell Viability Assay}

Cell viability was measured using the retention of acetoxymethyl ester of calcein (calcein-AM) in live cells as we described previously $[58,59]$. Calcein-AM is membrane-permeant and can be introduced into cells via incubation with culture media. Once inside the cells, the non-fluorescent calcein-AM is hydrolyzed by intracellular esterases into the highly negatively charged green fluorescent calcein in the cytoplasm of live cells. Calcein-AM cell viability assay was conducted in 48-well plates. For calcein-AM cell viability assays in MIO-M1 Müller cells, $1 \times 10^{4}$ cells were seeded in each well until $80 \%$ confluence and then the media were replaced by $200 \mu \mathrm{L}$ of various stress media and incubated for $24 \mathrm{~h}$. Cell viability assay was conducted by addition of $100 \mu \mathrm{L}$ of $12 \mu \mathrm{M}$ calcein-AM (Molecular Probes, Invitrogen) into each well to form a final working concentration of $4 \mu \mathrm{M}$ calcein-AM. Cells were incubated for $60 \mathrm{~min}$ to allow the dye to be taken up. For calcein-AM cell viability assays in Y79 cells, $2 \times 10^{4}$ cells were directly incubated in $200 \mu \mathrm{L}$ of test media for $24 \mathrm{~h}$ and then a volume of $100 \mu \mathrm{L}$ of $12 \mu \mathrm{M}$ calcein-AM was added to each well. Fluorescence measurements were performed $60 \mathrm{~min}$ after incubation using a Tecan Safire2 fluorescence multi-well plate reader (Tecan, Männedorf, Switzerland) with excitation/emission wavelengths at $485 / 535 \mathrm{~nm}$. Fluorescent images were also taken using an inverted fluorescent microscope to document the cell morphology after calcein-AM staining.

\subsection{Measurements of VEGF-A, NT3, BDNF, PEDF and IRBP in Conditioned Media Using Enzyme-Linked Immunosorbent Assays}

As FCS contains a complex mixture of growth factors, the production of VEGF-A, NT3, BDNF and PEDF in Müller cells and IRBP in photoreceptors were measured using enzyme-linked immunosorbent assays (ELISA) $24 \mathrm{~h}$ after incubating cells in test media containing $1 \%$ FCS and various concentrations of glucose along with and without $\mathrm{CoCl}_{2}(200 \mu \mathrm{M})$. In brief, conditioned media were collected from 6-well plates and ELISA was conducted to detect human VEGF-A (R\&D Systems, \#DY293B, Minneapolis, MN, USA), NT3 (Biosensis, \#BEK-2221, Thebarton, Australia), BDNF (R\&D Systems, \#DY248), PEDF (R\&D Systems, \#DY1177) and IRBP (LifeSpan Biosciences, \#LS-F7906, Seattle, WA, USA) according to 
the manufacturer's instructions. Results were normalized to levels of proteins extracted from cells where the conditioned media were collected.

\subsection{Western Blot Analysis}

Western blots were conducted to study changes in hypoxia-inducible factor- $\alpha(\mathrm{HIF} 1 \alpha)$, heat shock proteins (Hsp) 60 and 90 and redox proteins including thioredoxin 1 and 2 (TRX1, TRX2). Briefly, proteins were extracted from MIO-M1 Müller cells and Y79 photoreceptors and their concentrations were determined by bicinchoninic acid (BCA) assays (QuantiPro BCA assay kit, Sigma). Equal amounts of protein were subjected to sodium dodecyl sulfate polyacrylamide gel electrophoresis then transferred to a polyvinylidene difluoride membrane. Membranes were probed with primary antibodies against HIF1 $\alpha$ (1:500, Novus Biologicals \#NB-100-449, Littleton, CO, USA), Hsp60 (1:1000, Cell Signaling\#4870, Beverly, MA, USA), Hsp90 (1:1000, Cell Signaling\#4877), TRX1 (1:1000; Cell Signaling \#2429) and TRX2 (1:500, Proteintech\#13089-1-AP) and then incubated with secondary antibodies conjugated with horseradish peroxidise. Protein bands were visualized using the G:Box BioImaging system (Syngene, Cambridge, UK) and quantified using the GeneTools image scanning and analysis package (Syngene, software version 3.07(g)). Protein expression was normalized to $\alpha / \beta$ tubulin (1:2000; Cell Signaling \#2148), which serves as a loading control.

\subsection{Statistical Analysis}

Differences between study groups were analyzed using one-way analysis of variance (one-way ANOVA) followed by a post hoc Bonferroni's correction or Kruskal-Wallis tests for multiple comparisons using GraphPad Prism V.5.0 version statistics program (GraphPad Software, San Diego, CA, USA). A $p$-value $<0.05$ was considered to be statistically significant. Data are reported as mean \pm standard error of the mean (SEM) where applicable.

\section{Conclusion}

We have studied the potential adverse effects of aflibercept and ranibizumab on human Müller cells and retinoblastoma Y79 photoreceptors. Aflibercept and ranibizumab did not appear to affect Müller cells adversely. On the other hand, aflibercept appeared to stress Y79 photoreceptors more compared with ranibizumab. Aflibercept and ranibizumab both inhibited the production of IRBP in Y79 photoreceptors, with the most profound effect observed with aflibercept treatment. Our results indicate that the potential influence of aflibercept and ranibizumab on photoreceptors should be specifically monitored in clinical research.

Acknowledgments: We thank Astrid Limb for providing the MIO-M1 cells. This study was partially supported by grants from Novartis Australia and Lowy Medical Research Institute Pty Ltd. Mark Gillies is a fellow of Sydney Medical School Foundation and supported by a National Health and Medical Research Council (NH\&MRC) Practitioner Fellowship.

Author Contributions: Weiyong Shen and Mark C. Gillies conceived the project and wrote the article; Weiyong Shen and Belinda Yau designed experiments; Belinda Yau, So-Ra Lee, Ling Zhu and Michelle Yam performed experiments; Weiyong Shen, Belinda Yau and So-Ra Lee conducted data analysis. All authors agreed to be accountable for the content of the work.

Conflicts of Interest: Mark C. Gillies is an Advisory Board Member for Novartis Australia (Macquarie Park, NSW, Australia), Bayer Australia (Pymble, NSW, Australia), and Allergan Australia (Gordon, NSW, Australia). Mark C. Gillies is a fellow of Sydney Medical School Foundation and supported by a National Health and Medical Research Council (NH\&MRC) Practitioner Fellowship.

\section{References}

1. Miller, J.W.; Le Couter, J.; Strauss, E.C.; Ferrara, N. Vascular endothelial growth factor a in intraocular vascular disease. Ophthalmology 2013, 120, 106-114. [CrossRef] [PubMed]

2. Sene, A.; Chin-Yee, D.; Apte, R.S. Seeing through VEGF: Innate and adaptive immunity in pathological angiogenesis in the eye. Trends Mol. Med. 2015, 21, 43-51. [CrossRef] [PubMed] 
3. Jager, R.D.; Mieler, W.F.; Miller, J.W. Age-related macular degeneration. N. Engl. J. Med. 2008, 358, $2606-2617$. [CrossRef] [PubMed]

4. Antonetti, D.A.; Klein, R.; Gardner, T.W. Diabetic retinopathy. N. Engl. J. Med. 2012, 366, 1227-1239. [CrossRef] [PubMed]

5. Semeraro, F.; Morescalchi, F.; Duse, S.; Parmeggiani, F.; Gambicorti, E.; Costagliola, C. Aflibercept in wet AMD: Specific role and optimal use. Drug Des. Dev. Ther. 2013, 7, 711-722. [CrossRef] [PubMed]

6. Saint-Geniez, M.; Kurihara, T.; Sekiyama, E.; Maldonado, A.E.; D'Amore, P.A. An essential role for RPE-derived soluble VEGF in the maintenance of the choriocapillaris. Proc. Natl. Acad. Sci. USA 2009, 106, 18751-18756. [CrossRef] [PubMed]

7. Marneros, A.G.; Fan, J.; Yokoyama, Y.; Gerber, H.P.; Ferrara, N.; Crouch, R.K.; Olsen, B.R. Vascular endothelial growth factor expression in the retinal pigment epithelium is essential for choriocapillaris development and visual function. Am. J. Pathol. 2005, 167, 1451-1459. [CrossRef]

8. Byeon, S.H.; Lee, S.C.; Choi, S.H.; Lee, H.K.; Lee, J.H.; Chu, Y.K.; Kwon, O.W. Vascular endothelial growth factor as an autocrine survival factor for retinal pigment epithelial cells under oxidative stress via the VEGF-R2/PI3K/Akt. Investig. Ophthalmoil Vis. Sci. 2010, 51, 1190-1197. [CrossRef] [PubMed]

9. Foxton, R.H.; Finkelstein, A.; Vijay, S.; Dahlmann-Noor, A.; Khaw, P.T.; Morgan, J.E.; Shima, D.T.; Ng, Y.S. VEGF-A Is Necessary and sufficient for retinal neuroprotection in models of experimental glaucoma. Am. J. Pathol. 2013, 182, 1379-1390. [CrossRef] [PubMed]

10. Brar, V.S.; Sharma, R.K.; Murthy, R.K.; Chalam, K.V. Bevacizumab neutralizes the protective effect of vascular endothelial growth factor on retinal ganglion cells. Mol. Vis. 2010, 16, 1848-1853. [PubMed]

11. Hombrebueno, J.R.; Ali, I.H.; Xu, H.; Chen, M. Sustained intraocular VEGF neutralization results in retinal neurodegeneration in the Ins2(Akita) diabetic mouse. Sci. Rep. 2015, 5, 18316. [CrossRef] [PubMed]

12. Park, H.Y.; Kim, J.H.; Park, C.K. Neuronal cell death in the inner retina and the influence of vascular endothelial growth factor inhibition in a diabetic rat model. Am. J. Pathol. 2014, 184, 1752-1762. [CrossRef] [PubMed]

13. Saint-Geniez, M.; Maharaj, A.S.; Walshe, T.E.; Tucker, B.A.; Sekiyama, E.; Kurihara, T.; Darland, D.C.; Young, M.J.; D'Amore, P.A. Endogenous VEGF is required for visual function: Evidence for a survival role on Müller cells and photoreceptors. PLoS ONE 2008, 3, e3554. [CrossRef] [PubMed]

14. Kurihara, T.; Westenskow, P.D.; Bravo, S.; Aguilar, E.; Friedlander, M. Targeted deletion of Vegfa in adult mice induces vision loss. J. Clin. Investig. 2012, 122, 4213-4217. [CrossRef] [PubMed]

15. Bringmann, A.; Pannicke, T.; Grosche, J.; Francke, M.; Wiedemann, P.; Skatchkov, S.N.; Osborne, N.N.; Reichenbach, A. Müller cells in the healthy and diseased retina. Prog. Retin. Eye Res. 2006, 25, 397-424. [CrossRef] [PubMed]

16. Yang, X.M.; Yafai, Y.; Wiedemann, P.; Kuhrt, H.; Wang, Y.S.; Reichenbach, A.; Eichler, W. Hypoxia-induced upregulation of pigment epithelium-derived factor by retinal glial (Müller) cells. J. Neurosci. Res. 2012, 90, 257-266. [CrossRef] [PubMed]

17. Unterlauft, J.D.; Eichler, W.; Kuhne, K.; Yang, X.M.; Yafai, Y.; Wiedemann, P.; Reichenbach, A.; Claudepierre, T. Pigment epithelium-derived factor released by Müller glial cells exerts neuroprotective effects on retinal ganglion cells. Neurochem. Res. 2012, 37, 1524-1533. [CrossRef] [PubMed]

18. Shen, W.; Zhu, L.; Lee, S.R.; Chung, S.H.; Gillies, M.C. Involvement of NT3 and P75(NTR) in photoreceptor degeneration following selective Müller cell ablation. J. Neuroinflam. 2013, 10, 137. [CrossRef] [PubMed]

19. Vogler, S.; Hollborn, M.; Berk, B.A.; Pannicke, T.; Seeger, J.; Wiedemann, P.; Reichenbach, A.; Bringmann, A. Ischemic regulation of brain-derived neurotrophic factor-mediated cell volume and TrkB expression in glial (Müller) and bipolar cells of the rat retina. Graefes Arch. Clin. Exp. Ophthalmol. 2016, 254, 497-503. [CrossRef] [PubMed]

20. Malik, D.; Tarek, M.; Caceres del Carpio, J.; Ramirez, C.; Boyer, D.; Kenney, M.C.; Kuppermann, B.D. Safety profiles of anti-VEGF drugs: Bevacizumab, ranibizumab, aflibercept and ziv-aflibercept on human retinal pigment epithelium cells in culture. Br. J. Ophthalmol. 2014, 98 (Suppl. 1), i11-i16. [CrossRef] [PubMed]

21. Klettner, A.; Mohle, F.; Roider, J. Intracellular bevacizumab reduces phagocytotic uptake in RPE cells. Graefes Arch. Clin. Exp. Ophthalmol. 2010, 248, 819-824. [CrossRef] [PubMed]

22. Peng, S.; Adelman, R.A.; Rizzolo, L.J. Minimal effects of VEGF and anti-VEGF drugs on the permeability or selectivity of RPE tight junctions. Investig. Ophthalmol. Vis. Sci. 2010, 51, 3216-3225. [CrossRef] [PubMed] 
23. Schnichels, S.; Hagemann, U.; Januschowski, K.; Hofmann, J.; Bartz-Schmidt, K.U.; Szurman, P.; Spitzer, M.S.; Aisenbrey, S. Comparative toxicity and proliferation testing of aflibercept, bevacizumab and ranibizumab on different ocular cells. Br. J. Ophthalmol. 2013, 97, 917-923. [CrossRef] [PubMed]

24. Salminen, A.; Ojala, J.; Kaarniranta, K.; Hiltunen, M.; Soininen, H. Hsp90 regulates tau pathology through co-chaperone complexes in Alzheimer's disease. Prog. Neurobiol. 2011, 93, 99-110. [CrossRef] [PubMed]

25. Bross, P.; Magnoni, R.; Bie, A.S. Molecular chaperone disorders: Defective Hsp60 in neurodegeneration. Curr. Top. Med. Chem. 2012, 12, 2491-2503. [CrossRef] [PubMed]

26. Vlamis-Gardikas, A.; Holmgren, A. Thioredoxin and glutaredoxin isoforms. Methods Enzymol. 2002, 347, 286-296. [PubMed]

27. Seigel, G.M.; Notter, M.F. Differentiation of Y79 retinoblastoma cells induced by succinylated concanavalin A. Cell Growth Differ. 1993, 4, 1-7. [PubMed]

28. Rehemtulla, A.; Warwar, R.; Kumar, R.; Ji, X.; Zack, D.J.; Swaroop, A. The basic motif-leucine zipper transcription factor $\mathrm{Nrl}$ can positively regulate rhodopsin gene expression. Proc. Natl. Acad. Sci. USA 1996, 93, 191-195. [CrossRef] [PubMed]

29. Craft, C.M.; Xu, J.; Slepak, V.Z.; Zhan-Poe, X.; Zhu, X.; Brown, B.; Lolley, R.N. PhLPs and PhLOPs in the phosducin family of G $\beta \gamma$ binding proteins. Biochemistry 1998, 37, 15758-15772. [CrossRef] [PubMed]

30. Li, A.; Zhu, X.; Craft, C.M. Retinoic acid upregulates cone arrestin expression in retinoblastoma cells through a Cis element in the distal promoter region. Investig. Ophthalmol. Vis. Sci. 2002, 43, 1375-1383.

31. Garcia-Ramirez, M.; Hernandez, C.; Villarroel, M.; Canals, F.; Alonso, M.A.; Fortuny, R.; Masmiquel, L.; Navarro, A.; Garcia-Arumi, J.; Simo, R. Interphotoreceptor retinoid-binding protein (IRBP) is downregulated at early stages of diabetic retinopathy. Diabetologia 2009, 52, 2633-2641. [CrossRef] [PubMed]

32. Ozaki, H.; Yu, A.Y.; Della, N.; Ozaki, K.; Luna, J.D.; Yamada, H.; Hackett, S.F.; Okamoto, N.; Zack, D.J.; Semenza, G.L.; et al. Hypoxia inducible factor- $1 \alpha$ is increased in ischemic retina: Temporal and spatial correlation with VEGF expression. Investig. Ophthalmol. Vis. Sci. 1999, 40, 182-189.

33. Bai, Y.; Ma, J.X.; Guo, J.; Wang, J.; Zhu, M.; Chen, Y.; Le, Y.Z. Müller cell-derived VEGF is a significant contributor to retinal neovascularization. J. Pathol. 2009, 219, 446-454. [CrossRef] [PubMed]

34. Kvanta, A.; Steen, B.; Seregard, S. Expression of vascular endothelial growth factor (VEGF) in retinoblastoma but not in posterior uveal melanoma. Exp. Eye Res. 1996, 63, 511-518. [CrossRef] [PubMed]

35. De Gooyer, T.E.; Stevenson, K.A.; Humphries, P.; Simpson, D.A.; Gardiner, T.A.; Stitt, A.W. Retinopathy is reduced during experimental diabetes in a mouse model of outer retinal degeneration. Investig. Ophthalmol. Vis. Sci. 2006, 47, 5561-5568. [CrossRef] [PubMed]

36. Arden, G.B.; Sidman, R.L.; Arap, W.; Schlingemann, R.O. Spare the rod and spoil the eye. Br. J. Ophthalmol. 2005, 89, 764-769. [CrossRef] [PubMed]

37. Arden, G.B. The absence of diabetic retinopathy in patients with retinitis pigmentosa: Implications for pathophysiology and possible treatment. Br. J. Ophthalmol. 2001, 85, 366-370. [CrossRef] [PubMed]

38. Du, Y.; Veenstra, A.; Palczewski, K.; Kern, T.S. Photoreceptor cells are major contributors to diabetes-induced oxidative stress and local inflammation in the retina. Proc. Natl. Acad. Sci. USA 2013, 110, 16586-16591. [CrossRef] [PubMed]

39. Joyal, J.S.; Sun, Y.; Gantner, M.L.; Shao, Z.; Evans, L.P.; Saba, N.; Fredrick, T.; Burnim, S.; Kim, J.S.; Patel, G.; et al. Retinal lipid and glucose metabolism dictates angiogenesis through the lipid sensor Ffar1. Nat. Med. 2016, 22, 439-445. [CrossRef] [PubMed]

40. Puddu, A.; Sanguineti, R.; Traverso, C.E.; Viviani, G.L.; Nicolo, M. Response to anti-VEGF-A treatment of retinal pigment epithelial cells in vitro. Eur. J. Ophthalmol. 2016, 26, 425-430. [CrossRef] [PubMed]

41. Nishijima, K.; Ng, Y.S.; Zhong, L.C.; Bradley, J.; Schubert, W.; Jo, N.; Akita, J.; Samuelsson, S.J.; Robinson, G.S.; Adamis, A.P.; et al. Vascular endothelial growth factor-A is a survival factor for retinal neurons and a critical neuroprotectant during the adaptive response to ischemic injury. Am. J. Pathol. 2007, 171, 53-67. [CrossRef] [PubMed]

42. Klettner, A.; Tahmaz, N.; Dithmer, M.; Richert, E.; Roider, J. Effects of aflibercept on primary RPE cells: Toxicity, wound healing, uptake and phagocytosis. Br. J. Ophthalmol. 2014, 98, 1448-1452. [CrossRef] [PubMed]

43. Klettner, A.K.; Kruse, M.L.; Meyer, T.; Wesch, D.; Kabelitz, D.; Roider, J. Different properties of VEGF-antagonists: Bevacizumab but not Ranibizumab accumulates in RPE cells. Graefes Arch. Clin. Exp. Ophthalmol. 2009, 247, 1601-1608. [CrossRef] [PubMed] 
44. Inan, U.U.; Avci, B.; Kusbeci, T.; Kaderli, B.; Avci, R.; Temel, S.G. Preclinical safety evaluation of intravitreal injection of full-length humanized vascular endothelial growth factor antibody in rabbit eyes. Investig. Ophthalmol. Vis. Sci. 2007, 48, 1773-1781. [CrossRef] [PubMed]

45. Avci, B.; Avci, R.; Inan, U.U.; Kaderli, B. Comparative evaluation of apoptotic activity in photoreceptor cells after intravitreal injection of bevacizumab and pegaptanib sodium in rabbits. Investig. Ophthalmol. Vis. Sci. 2009, 50, 3438-3446. [CrossRef] [PubMed]

46. Januschowski, K.; Schnichels, S.; Hagemann, U.; Koch, V.; Hofmann, J.; Spitzer, M.S.; Bartz-Schmidt, K.U.; Szurman, P.; Luke, M.; Aisenbrey, S. Electrophysiological toxicity testing of VEGF Trap-Eye in an isolated perfused vertebrate retina organ culture model. Acta Ophthalmol. 2014, 92, e305-e311. [CrossRef] [PubMed]

47. Harada, T.; Harada, C.; Kohsaka, S.; Wada, E.; Yoshida, K.; Ohno, S.; Mamada, H.; Tanaka, K.; Parada, L.F.; Wada, K. Microglia-Müller glia cell interactions control neurotrophic factor production during light-induced retinal degeneration. J. Neurosci. 2002, 22, 9228-9236. [PubMed]

48. Hu, L.M.; Luo, Y.; Zhang, J.; Lei, X.; Shen, J.; Wu, Y.; Qin, M.; Unver, Y.B.; Zhong, Y.; Xu, G.T.; et al. EPO reduces reactive gliosis and stimulates neurotrophin expression in Müller cells. Front. Biosci. 2011, 3, 1541-1555.

49. Fu, S.; Dong, S.; Zhu, M.; Sherry, D.M.; Wang, C.; You, Z.; Haigh, J.J.; Le, Y.Z. Müller glia are a major cellular source of survival signals for retinal neurons in diabetes. Diabetes 2015, 64, 3554-3563. [CrossRef] [PubMed]

50. Unterlauft, J.D.; Claudepierre, T.; Schmidt, M.; Müller, K.; Yafai, Y.; Wiedemann, P.; Reichenbach, A.; Eichler, W. Enhanced survival of retinal ganglion cells is mediated by Müller glial cell-derived PEDF. Exp. Eye Res. 2014, 127, 206-214. [CrossRef] [PubMed]

51. Gonzalez-Fernandez, F.; Landers, R.A.; Glazebrook, P.A.; Fong, S.L.; Liou, G.I.; Lam, D.M.; Bridges, C.D. An extracellular retinol-binding glycoprotein in the eyes of mutant rats with retinal dystrophy: Development, localization, and biosynthesis. J. Cell Biol. 1984, 99, 2092-2098. [CrossRef] [PubMed]

52. Ishikawa, M.; Sawada, Y.; Yoshitomi, T. Structure and function of the interphotoreceptor matrix surrounding retinal photoreceptor cells. Exp. Eye Res. 2015, 133, 3-18. [CrossRef] [PubMed]

53. Den Hollander, A.I.; McGee, T.L.; Ziviello, C.; Banfi, S.; Dryja, T.P.; Gonzalez-Fernandez, F.; Ghosh, D.; Berson, E.L. A homozygous missense mutation in the IRBP gene (RBP3) associated with autosomal recessive retinitis pigmentosa. Investig. Ophthalmol. Vis. Sci. 2009, 50, 1864-1872. [CrossRef] [PubMed]

54. Sands, M.; Howell, K.; Costello, C.M.; McLoughlin, P. Placenta growth factor and vascular endothelial growth factor B expression in the hypoxic lung. Respir. Res. 2011, 12, 17. [CrossRef] [PubMed]

55. Balaiya, S.; Ferguson, L.R.; Chalam, K.V. Evaluation of sirtuin role in neuroprotection of retinal ganglion cells in hypoxia. Investig. Ophthalmol. Vis. Sci. 2012, 53, 4315-4322. [CrossRef] [PubMed]

56. Yang, C.; Lafleur, J.; Mwaikambo, B.R.; Zhu, T.; Gagnon, C.; Chemtob, S.; Di Polo, A.; Hardy, P. The role of lysophosphatidic acid receptor (LPA1) in the oxygen-induced retinal ganglion cell degeneration. Investig. Ophthalmol. Vis. Sci. 2009, 50, 1290-1298. [CrossRef] [PubMed]

57. Yuan, Y.; Hilliard, G.; Ferguson, T.; Millhorn, D.E. Cobalt inhibits the interaction between hypoxia-inducible factor- $\alpha$ and von Hippel-Lindau protein by direct binding to hypoxia-inducible factor- $\alpha$. J. Biol. Chem. 2003, 278, 15911-15916. [CrossRef] [PubMed]

58. Shen, W.; Li, S.; Chung, S.H.; Gillies, M.C. Retinal vascular changes after glial disruption in rats. J. Neurosci. Res. 2010, 88, 1485-1499. [CrossRef] [PubMed]

59. Shen, W.; Zhang, J.; Chung, S.H.; Hu, Y.; Ma, Z.; Gillies, M.C. Submacular DL- $\alpha$-aminoadipic acid eradicates primate photoreceptors but does not affect luteal pigment or the retinal vasculature. Investig. Ophthalmol. Vis. Sci. 2011, 52, 119-127. [CrossRef] [PubMed]

(C) 2017 by the authors. Licensee MDPI, Basel, Switzerland. This article is an open access article distributed under the terms and conditions of the Creative Commons Attribution (CC BY) license (http:/ / creativecommons.org/licenses/by/4.0/). 